\title{
Rencana Induk Sistem Penyediaan Air Minum Kabupaten Kebumen
}

\author{
Master Plan of Kebumen Water Suplly System
}

\author{
Muhammad Arief Setiawan ${ }^{* 1)}$, Dwi Siwi Handayani1), dan Irawan Wisnu Wardana ${ }^{1)}$ \\ ${ }^{1)}$ Program Studi Teknik Lingkungan, Universitas Diponegoro, \\ Jl. Prof. Soedarto, SH Tembalang, Semarang, 1269 \\ ${ }^{*}$ E-mail: setiawanarief22@yahoo.com
}

\begin{abstract}
Abstrak
Kabupaten Kebumen berada di Provinsi Jawa Tengah dengan luas wilayah sebesar 128.111,50 ha dan jumlah penduduk pada tahun 2013 tercatat 1.183.763 jiwa. Tingkat pelayanan air minum oleh PDAM Tirta Bumi Sentosa sebesar $31 \%$ atau 398.588 jiwa, sedangkan daerah pelayanan PAMSIMAS sebesar 6\%. Proyeksi penduduk dan kebutuhan air di tahun 2033, yaitu dengan menentukan jumlah penduduk menggunakan metode aritmatika atau dengan tingkat kebutuhan air bersih 94 ltr/org/hari dengan faktor harian 1,01 dan faktor jam puncak 1,31. Kebutuhan Air pelayanan PDAM 2.441,64 liter/detik pada tahun 2033, sedangkan kebutuhan air non-PDAM 261,05 liter/detik pada tahun 2033. Sumber air baku menggunakan MA Goa Barat kapasitas 100 liter/detik, Bendung Pejengkolan kapasitas 400 liter/detik, dan Sungai Luk Ulo kapasitas 100 liter/detik.
\end{abstract}

Kata kunci: Faktor, Management, MDGs, Teknis, PAMSIMAS, RPJMN.

\begin{abstract}
Kebumen District is located in Central Java Province with an area of 128,111.50 ha, and the population recorded in 2013 was 1,183,763. The level of potable water service by PDAM Tirta Bumi Sentosa was $31 \%$ or 398,588 people, while PAMSIMAS service area was 6\%. Projection of population and water needs was done using arithmetic method to determine the population, or clean water requirement of $94 \mathrm{l} /$ person/day, with daily factor of 1.01 and peak hour factor 1.31. It was found that water needs to be served by PDAM would amount to 2,441.64 l/s in 2033, while that not served by PDAM would reach $261.05 \mathrm{l} / \mathrm{s}$ in 2033. The sources of raw water include MA Goa Barat with a capacity of $100 \mathrm{l} / \mathrm{s}$, Bendung Pejengkolan at $400 \mathrm{l} / \mathrm{s}$, and Luk Ulo River at $100 \mathrm{l} / \mathrm{s}$.
\end{abstract}

Keywords: Factor, Management, MDGs, Technical, PAMSIMAS, RPJMN.

\section{PENDAHULUAN}

Kabupaten Kebumen terletak di Provinsi Jawa Tengah yang mempunyai luas wilayah 128.111,50 hektar, terdiri dari 26 kecamatan, 459 kelurahan dengan jumlah penduduk 1.183.763 jiwa pada tahun 2013. PDAM
Kabupaten Kebumen memiliki jumlah pelanggan sebanyak 18.129 pada tahun 2013 dengan cakupan pelayanan sebesar $30,6 \%$. Hal ini masih dibawah MDGs pelayanan air minum sebesar $80 \%$, sedangkan tingkat kehilangan air sebesar 34,79\%. Hal ini tidak sesuai pada Peraturan Pemerintah No 18 
tahun 2007 dengan tingkat kehilangan air sebesar 20\%. Belum adanya rencana induk sistem penyediaan air di Kabupaten Kebumen yang memuat rencana umum, rencana jaringan, program dan kegiatan pengembangan, kriteria dan standar pelayanan, rencana sumber dan alokasi air baku, rencana keterpaduan dengan prasarana dan sarana sanitasi, rencana pembiayaan dan rencanan kelembagaan. Hal tersebut membuat tingkat pelayanan air bersih masih kurang, sedangkan potensi sumber air baku yang ada di Kebumen sangatlah melimpah. Oleh karena itu, diperlukan perencanaan yang baik untuk mengelola sumber air baku agar memenuhi kebutuhan air minum untuk masyarakat di Kabupaten Kebumen.

\section{METODA}

Kabupaten Kebumen terletak di Provinsi Jawa Tengah, terdiri dari 26 kecamatan dengan luas wilayah sebesar $128.111,50$ ha yang merupakan daerah pantai, perbukitan dan sebagian besar daerah dataran. Jumlah penduduk berdasarkan data tahun 2013 sebanyak 1.179.826 jiwa yang terdiri dari laki-laki 631.679 jiwa dan perempuan 548.147 jiwa. Pertumbuhan penduduk ratarata dalam kurun waktu 10 tahun terakhir adalah sebesar $0,75 \%$ per tahunnya. Pemakaiaan air rata-rata untuk pelanggan rumah tangga sebesar 94,43 1/org/hari atau sebesar 17,23 $\mathrm{m}^{3} /$ bulan sebesar dengan asumsi 1 SR (sambungan rumah) 4 orang, sedangkan kontinuitas air yang distribusikan berkisar 21,75 jam per hari. Kegiatan penyediaan air minum di daerah pedesaan di wilayah Kabupaten Kebumen telah dilakukan pembangunan PAMSIMAS. Jumlah penduduk Kabupaten Kebumen yang terlayani 118.992 jiwa atau $10,05 \%$ dari jumlah penduduk keseluruhan sebanyak 1.183.766 jiwa, sedangkan penduduk di wilayah teknis yang terlayani sebanyak 118.992 jiwa atau $16,23 \%$ dari jumlah penduduk yang ada jaringan pipa PDAM sebanyak 733.054 jiwa. Cakupan pelayaan masih dibawah target RPJMN tahun 2012 yaitu sebesar $63 \%$ dikarenakan terbatasnya jaringan perpipaan PDAM Tirta Bumi Sentosa Kab.Kebumen, luasnya wilayah yang harus dilayani, penduduk tinggal di pegunungan dan adanya program penyedian air bersih yang dilakukan oleh pemda dan masyarakat secara mandiri. PDAM Kebumen mengkelompokan jenis pelanggan ada 4 golongan, yaitu sosial, non niaga, niaga serta pemerintahan.

\section{HASIL DAN PEMBAHASAN}

\section{Proyeksi penduduk dan kebutuhan air bersih}

Metode yang digunakan untuk memproyeksikan jumlah penduduk Kabupaten Kebumen mengalami pertambahan penduduk dikarenakan tingkat kelahiran tiap tahun sebesar $10 \%$, tingkat kematian $1 \%$ tahun dan transmigrasi penduduk 8\%/tahun yang dapat dilihat pada Gambar 1. Kebutuhan air untuk layanan PDAM lebih besar dibanding layanan non PDAM, karena tingkat pelayanan PDAM sebesar $81 \%$ sedangkan non PDAM sebesar $19 \%$ pada akhir tahun 2033. Rata-rata pertumbuhan penduduk pada daerah pelayanan PDAM sebesar $1,5 \%$ setiap tahun. Kebutuhan air bersih Kabupaten Kebumen dapat dilihat pada Gambar 2.

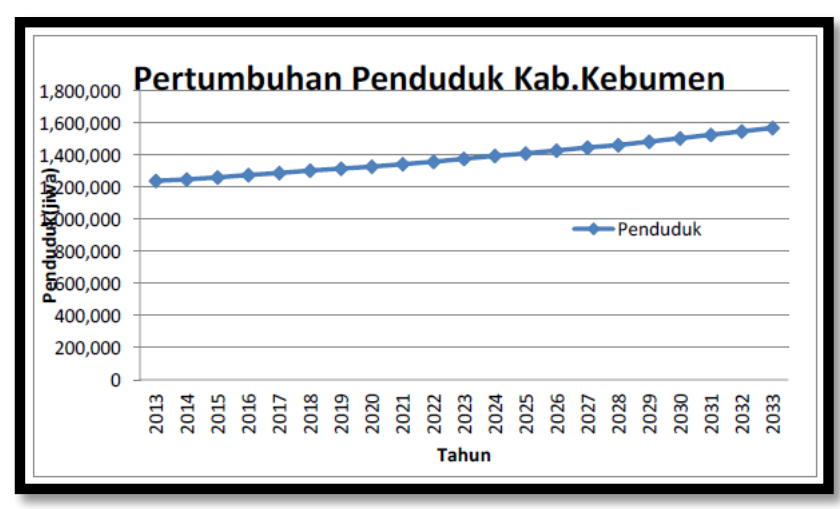

Gambar 1. Proyeksi Pertumbuhan Penduduk Kabupaten Kebumen 


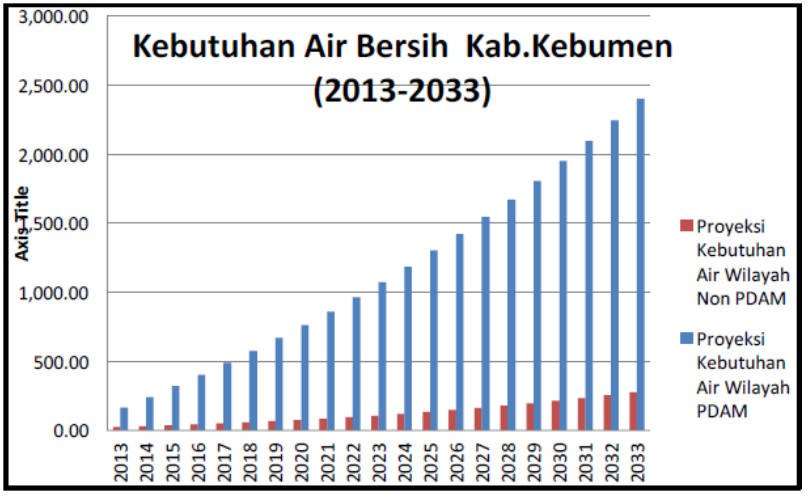

Gambar 2. Kebutuhan Air Bersih Kabupaten Kebumen

\section{Alternatif sumber air baku}

Pemilihan sumber air baku untuk air minum harus memperhatikan aspek kualitas, kuantitas dan kontinuitas. Syarat kualitas harus sesuai dengan ketentuan Peraturan Menteri Kesehatan Nomor 492 Tahun 2010. Kabupaten Kebumen memiliki potensi air permukaan yang cukup besar, baik mata air maupun sungai/waduk. Oleh karena itu, alternatif air baku untuk pengembangan SPAM diprioritaskan menggunakan air permukaan dan mata air, baik untuk wilayah pelayanan PDAM Tirta Bumi Sentosa maupun wilayah pelayanan non-PDAM.

Menurut Permen PU No 18 tahun 2007 pemilihan sumber air baku harus memenuhi kuantitas, kontinuitas dan kualitas air baku. Sumber mata air yang direncanakan sebesar 100 liter/detik dari MA Goa Barat dan air permukaan sebesar 500 liter/detik yang berasal dari Bendung Pejengkolan yaitu 400 liter/detik dan Sungai Luk Ulo yaitu 100 liter/detik. Sumber air baku pelayanan non PDAM mengunakan sumber air baku mata air atau sumur, sesuai potensi sumber yang ada didaerah tersebut.

\section{Analisis sistem perencanaan SPAM}

Sumber air baku eksisiting yang digunakan untuk mensuplai kebutuhan air wilayah PDAM Tirta Bumi Sentosa mencapai 300 liter/detik. Kebutuhan air baku untuk pelayanan PDAM tahun 2033 membutuhkan 2.441,3 L/Detik, sedangkan kebutuhan air bersih untuk pelayanan non PDAM tahun 2033 sebesar 261,05 liter/detik. Tahapan program dibagi menjadi 3 tahap pengembangan SPAM PDAM Kebumen, yaitu jangka pendek (2014-2018) yang berupa kegiatan fisik/ pembangunan unit air baku sampai unit pelayanan, jangka menengah (2019-2028) berupa kegiatan penambahan SR tiap IKK yang ada di Kabupaten Kebumen dan kegiatan non fisik, serta jangka panjang (2029-2033) berupa kegiatan penambahn SR pada IKK yang ada. Tahap pada pelayanan non PDAM yakni dengan mengembangankan tingkat pelayanan, serta peningkatan kapasitas sistem yang sudah ada.

\section{a. Supply and Demand Layanan PDAM}

Tahap 1 (2014-2018), pada tahun 2016 melakukan penambahan kapasitas dengan sumber air baku berasal dari Bendung Pejengkolan 400 liter/detik, yang masingmasing 200 liter/detik untuk melayani Kecamatan Kebumen dan IKK Poncowarno. Pada pentahapan ini disesuaikan RI-SPAM Regional Kebumen Purworejo tahun 2013.

Pada tahap 2 (2019-2028), pada tahun 2022 penggunaan sumber air baku Sungai Luk Ulo 100 liter/detik untuk melayani IKK Sadang. MA Goa Barat 100 liter/detik untuk melayani IKK Puring, MA Madayana 180 liter/detik dan MA Kaliwinong sebesar 190 liter/detik. Pada tahun 2025 melakukan penambahan kapasitas berasal dari sumber air baku Sungai Kedungbener 100 liter/detik, MA Banyumudal 130 liter/detik dan Sungai Padegolan 97 liter/detik. Pada tahap 3 (2029-2033), pada tahun 2033 melakukan penambahan kapasitas Bendung Pejengkolan 90 liter/detik dan Waduk Sempor 50 liter/detik. 


\section{b. Supply and Demand Layanan non PDAM}

Supply and Demand Wilayah Pelayanan non PDAM diperoleh kapasitas sumber air yang terpasang setiap kecamatan dan sumber air baku yang digunakan. Pada tahun 2027 menambah kapasitas sebesar 52 liter/detik dan pada tahun 2031 sebesar 51 liter/detik. Sumber air baku untuk wilayah pelayanan non PDAM sumber dari mata air atau sumur, disesuaikan dengan kondisi wilayah. Pada tahun 2033 jumlah penduduk terlayani 295.448 jiwa, dengan tingkat pelayanan sebesar $19 \%$ dan jumlah SR sebanyak 73.862 .

\section{KESIMPULAN}

Rencana Induk Sistem Penyediaan Air Minum Kabupaten Kebumen diperoleh kesimpulan, sebagai berikut:

1. Kebutuhan Air di Kabupaten Kebumen diproyeksikan sesuai dengan daerah pelayanan SPAM yaitu wilayah pelayanan PDAM dan pelayanan Non PDAM. Kebutuhan Air pelayanan PDAM di tahun 2013 sekitar 242,69 liter/detik meningkat menjadi 2.441,64 liter/detik pada tahun 2033, sedangkan kebutuhan air di Non PDAM di tahun 2013 sekitar 29,36 liter/detik meningkat menjadi 261,05 liter/detik pada tahun 2033.

2. Rencana air baku yang bisa dimanfaatkan untuk memenuhi kebutuhan air di Kabupaten Kebumen meliputi mata air dan air permukaan, yaitu MA Goa Barat kapasitas 100 liter/detik, Bendung Pejengkolan kapasitas 400 liter/detik, dan Sungai Luk Ulo kapasitas 100 liter/detik. Sumber air baku yang sudah dimanfaatkan PDAM maupun non PDAM dapat dioptimalkan dengan menambah kapasitas sistem.

\section{DAFTAR PUSTAKA}

BAPPEDA Kebumen. (2012). Buku Putih Sanitasi Kabupaten Kebumen.
Pemerintah Kabupaten Kebumen: Kebumen.

BPKP. (2012). Laporan Hasil Audit Kinerja PDAM Tirta Bumi Sentosa Kebumen. BPKP Press:Yogyakarta.

BPS. (2013) .Kebumen dalam Angka 2013. BPS Press:Kab.Kebumen.

Cipatakaru. (2012). Data Penerima Pamsimas Kabupaten Kebumen. Cipatakur Press:Semarang.

ESDM. (2008). Manajemen Air Tanah Berbasisi Cekungan Air Tanah". ESDM Press:Jakarta.

Mawardi, Muhjidin. (2012). Rekayasa Konservasi Tanah dan Air. Bursa Ilmu:Yogyakarta.

PDAM Kebumen. (2013). Laporan Teknik. PDAM Kebumen press:Kebumen.

PDAM Kebumen. (2011). Coorporate Plan PDAM Tirta Bumi Sentosa Kebumen 2011-2015. PDAM Kebumen Press:Kebumen.

Peraturan Daerah No 7 Tahun 2012 Tentang PDAB Tirta Utama Jawa Tengah.

Peraturan Menteri Pekerjaan Umum No.21/PRT/M/2009 tentang Pedoman Teknis Kelayakan Investasi Pengembangan Sistem Penyedian Air Minum.

Peraturan Menteri Pekerjaan Umum No.34/Permen/M/2006 tentang Prasarana dan Sarana Permukiman Rakyat.

Peraturan Pemerintah No.16 Tahun 2005 tentang Pengembangan Sistem Penyediaan Air Minum.

Peraturan Menteri Pekerjaan Umum No.18/PRT/M/2007 Tentang Penyelenggaraan Pengembangan Sistem Penyediaan Air Minum.

Rencana Induk Sistem Penyedian Air Minum Regional Kebumen Purworejo tahun 2013. 